\title{
CCAAT enhancer binding protein $\beta$ has a crucial role in regulating breast cancer cell growth via activating the TGF- $\beta$-Smad3 signaling pathway
}

\author{
JING CAO $^{1}$, MENG WANG ${ }^{2}$ and TAO WANG ${ }^{2}$ \\ Departments of ${ }^{1}$ Pharmacy and ${ }^{2}$ Opthalmology, \\ Linyi People's Hospital of Shandong University, Linyi, Shandong 276000, P.R. China
}

Received April 2, 2016; Accepted March 17, 2017

DOI: $10.3892 /$ etm.2017.4659

\begin{abstract}
The aim of the present study was to examine the effect of CCAAT enhancer binding protein $\beta(\mathrm{C} / \mathrm{EBP} \beta)$ on human breast cancer cells. The plasmids $\mathrm{pCDH}-\mathrm{C} / \mathrm{EBP} \beta$ and pLKO.1-shC/EBP $\beta$ were constructed and were infected into MDA-MB-468 cells, to provide C/EBP $\beta$ overexpressing and C/EBP $\beta$ knockdown cells, respectively. Cell viability, cell cycle and apoptosis were observed by MTT assay and flow cytometry analysis. Protein expression levels of C/EBP $\beta$, TGF- $\beta 1$, P-Smad 3 and Smad3 were detected by western blotting. MTT assay showed that the absorbance of MDA-MB-468 cells in the $\mathrm{pCDH}-\mathrm{C} / \mathrm{EBP} \beta$ group was increased, whereas that in the pLKO.1-shC/EBP $\beta$ group was decreased, compared with the respective control at 48 and $72 \mathrm{~h}$. Flow cytometric analysis indicated that the percentage of cells in the G2 phase was significantly increased in the $\mathrm{pCDH}-\mathrm{C} / \mathrm{EBP} \beta$ group $(\mathrm{P}<0.05)$ and decreased in the pLKO.1-shC/EBP $\beta$ group compared with the respective control group. The proportion of apoptotic cells was decreased in the $\mathrm{pCDH}-\mathrm{C} / \mathrm{EBP} \beta$ group and increased in the $\mathrm{pLKO} .1-\mathrm{shC} / \mathrm{EBP} \beta$ group compared with the controls. The scratch-wound assay revealed that MDA-MB-468 cells depleted of C/EBP $\beta$ exhibited reduced motility compared with the control cells. Moreover, western blotting demonstrated that $\mathrm{pCDH}-\mathrm{C} / \mathrm{EBP} \beta$ increased transforming growth factor (TGF) $\beta 1$ and P-Smad3 protein expression and decreased Smad3 protein expression, whereas pLKO.1-shC/EBP $\beta$ decreased TGF $\beta 1$ and $\mathrm{P}-\mathrm{Smad} 3$ protein expression and increased $\mathrm{Smad} 3$ protein expression levels. The present study demonstrated that C/EBP $\beta$ has a crucial role in regulating breast cancer cell growth through activating TGF- $\beta$-Smad 3 signaling. These findings suggest that $\mathrm{C} / \mathrm{EBP} \beta$ may be a potential therapeutic target for breast cancer; however, in vivo studies are required to confirm this.
\end{abstract}

Correspondence to: Dr Tao Wang, Department of Ophthalmology, Linyi People's Hospital of Shandong University, 27 Jiefang Road, Linyi, Shandong 276000, P.R. China

E-mail: taowangsdu@163.com

Key words: CCAAT enhancer binding protein $\beta$, breast cancer, MDA-MB-468 cells, transforming growth factor- $\beta 1$, Smad3

\section{Introduction}

Breast cancer is one of the most common malignant tumors and the second most common cause of cancer-related fatality in the United States (1). Although the death rate of breast cancer has decreased with advances in prevention, surgical resection and adjuvant therapies, there were $\sim 232,340$ new cases of breast cancer and 39,620 associated fatalities in the United States in 2013 (1). Metastasis to vital organs such as lung, brain and bone is a major cause of mortality resulting from breast cancer (2). Therefore, it is essential to study the molecular mechanism of breast cancer and identify further effective diagnostic and treatment methods.

CCAAT enhancer binding protein $\beta$ (C/EBP $\beta$ ), a type of trans-acting factor, is one of the important members of the $\mathrm{C} / \mathrm{EBP}$ family (including $\mathrm{C} / \mathrm{EBP} \alpha, \beta, \gamma, \delta, \varepsilon$ and $\xi$ ) (3). $\mathrm{C} / \mathrm{EBP} \beta$ is able to bind to the DNA specific regulatory region and is involved in multiple cell processes, such as metabolism, hematopoiesis, adipogenesis, immune response and morphogenesis $(4,5)$. Additionally, C/EBP $\beta$ serves as a key factor in neuronal differentiation and apoptosis (6) and is involved in inflammatory processes and brain injury by regulating the expression levels of several genes, such as GRO1/KC, 24p3/LCN2 and TM4SF1/L6 (7). As observed in C/EBP $\beta$-null mice by Zhu et al (8), reduced levels of C/EBP $\beta$ result in cell apoptosis, and thus these mice display resistance to 7,12-dimethylbenz $[a]$ anthracene-induced skin tumorigenesis (8). Moreover, C/EBP $\beta$ has been shown to promote cell survival downstream of DNA damage by repressing p53 expression and activity (9).

Considerable research has demonstrated that $\mathrm{C} / \mathrm{EBP} \beta$ is an essential mediator of breast tumorigenesis. C/EBP $\beta$ has been indicated to be overexpressed at late stages of breast carcinogenesis (10), suggesting its potential role in the metastatic progression of breast cancer. $\mathrm{C} / \mathrm{EBP} \beta$ also has an important role in the evasion of metastatic breast cancer cells from the cytostatic effects of transforming growth factor (TGF)- $\beta$ (11). The loss of C/EBP $\beta$ promotes epithelial-mesenchymal transition (EMT) and invasion in breast cancer (12). Although $\mathrm{C} / \mathrm{EBP} \beta$ has been reported to be deregulated in breast cancer, the underlying mechanisms of the effects of C/EBP $\beta$ on breast cancer cells remain far from clear and require further elucidation. 
Table I. The primers for reverse transciption-quantitative polymerase chain reaction.

\begin{tabular}{lcc}
\hline Gene & Forward & Reverse \\
\hline C/EBP $\beta$ & CCTCGCAGGTCAAGAGCAAG & GAACAAGTTCCGCAGGGTG \\
GAPDH & TGTTGCCATCAATGACCCCTT & CTCCACGACGTACTCAGCG
\end{tabular}

$\mathrm{C} / \mathrm{EBP} \beta, \mathrm{CCAAT}$ enhancer binding protein $\beta$.

C/EBP functionally and physically interacts with TGF- $\beta 1$ signaling factors in astrocytes (13). TGF- $\beta 1$ has a key role in tumor pathogenesis, contributes to cell growth, invasion and metastasis, and inhibits host antitumor immune responses (14). A previous study indicated that the TGF- $\beta$ pathway may be considered a therapeutic target for tumor diseases (15). TGF- $\beta$ super family ligands bind to serine/threonine kinase receptors type II, which phosphorylate receptor type I (16). The receptor type I phosphorylates Smad2/3 (R-Smads), which combines with coSmad-Smad4 and R-Smad/coSmad complexes and subsequently shuttles into the nucleus to regulate the expression of their downstream genes (16). Several studies have suggested that activation of TGF- $\beta$-Smad signaling has a deteriorative effect on glioblastoma, and that inhibition of TGF- $\beta$ signaling reduces the growth and invasion of gliomas (17-19). However, studies concerning the interactions of $\mathrm{C} / \mathrm{EBP} \beta$ and the TGF- $\beta$ signaling pathway are limited.

The aim of the present study was to investigate whether $\mathrm{C} / \mathrm{EBP} \beta$ contributes to the development of breast cancer via the regulation of TGF- $\beta 1-S m a d 3$ signaling. In this study, a recombinant lentiviral vector containing the $\mathrm{C} / \mathrm{EBP} \beta$ gene was constructed and the effect of $\mathrm{C} / \mathrm{EBP} \beta$ on cell viability, cell cycle, cell apoptosis and TGF- $\beta 1-$ Smad3 signaling in the MDA-MB-468 human breast cancer cell line was investigated.

\section{Materials and methods}

Cell lines. The human breast cancer cell line, MDA-MB-468, was purchased from The Cell Bank of the Chinese Academy of Sciences (Shanghai, China). Cells were cultured in Dulbecco's modified Eagle's medium (DMEM; Gibco; Thermo Fisher Scientific, Inc., Waltham, MA, USA) supplemented with $10 \%$ fetal bovine serum (FBS; Gibco, Thermo Fisher Scientific, Inc.) at $37^{\circ} \mathrm{C}$ in an atmosphere containing $5 \% \mathrm{CO}_{2}$.

Construction of lentiviral vector. Human $\mathrm{C} / \mathrm{EBP} \beta$ gene was synthesized by Shanghai Sangon Biotech Co., Ltd. (Shanghai, China) and was cloned into pCDH lentiviral vector (System Biosciences, Mountain View, CA, USA). In the pCDH lentiviral vector, green fluorescent protein was a single transcript under the control of a CMV promoter and expressed after the transcription of the $\mathrm{C} / \mathrm{EBP} \beta$ gene. To knockdown $\mathrm{C} / \mathrm{EBP} \beta$ expression, the selected interfering [short hairpin (SH)] sequence 5'-CCT TTA GAC CCA TGG AAG TTT-3' was cloned into pLKO.1 vector (Sigma-Aldrich; merck KGgA, Darmstadt, Germany) after the oligonucleotides were annealed.

Packaging and infection of lentivirus vector. The lentiviral vectors $\mathrm{pCDH}-\mathrm{C} / \mathrm{EBP} \beta$ and $\mathrm{pLKO} \cdot 1-\mathrm{shC} / \mathrm{EBP} \beta$ were co-transfected with the corresponding helper plasmids into 293T cells (Cell bank, Shanghai Institutes for Biological Sciences, Chinese Academy of Sciences, Shanghai, China) using Lipofectamine ${ }^{\circledR} 2000$ (Invitrogen; Thermo Fisher Scientific, Inc.) After $6 \mathrm{~h}$ incubation at $37^{\circ} \mathrm{C}$ in a humidified atmosphere containing $5 \% \mathrm{CO}_{2}$, DMEM was exchanged for complete medium (containing 10\% FBS, Gibco; Thermo Fisher Scientific, Inc.). The supernatant was harvested after culturing for $48 \mathrm{~h}$ and concentrated by ultrafiltration. MDA-MB- 468 cells were infected with recombinant lentivirus $\mathrm{pCDH}-\mathrm{C} / \mathrm{EBP} \beta$, lentivirus $\mathrm{pCDH}$, lentivirus $\mathrm{pLKO} .1-\mathrm{shC} / \mathrm{EBP} \beta$ and the negative control (NC) lentivirus pLKO.1-shNC, respectively. MDA-MB-468 cells without infection served as the blank group. Medium was replaced with fresh medium $24 \mathrm{~h}$ post-infection and cells were collected $72 \mathrm{~h}$ post-infection for subsequent analysis.

Reverse transcription-quantitative polymerase chain reaction $(R T-q P C R)$. Cells were washed three times with PBS and total RNA was extracted using TRIzol (Invitrogen; Thermo Fisher Scientific, Inc.). Total RNA was treated with DNase to remove genomic DNA contamination. The Revert Aid First-Strand RT-PCR kit (Invitrogen; Thermo Fisher Scientific, Inc.) was used to synthesize cDNA from $250 \mathrm{ng}$ of each extracted RNA sample. cDNA was amplified in a $20-\mu 1$ reaction mixture containing $10 \mu 1$ of SYBR-Green PCR Supermix (Invitrogen; Thermo Fisher Scientific, Inc.), $100 \mathrm{ng}$ of cDNA template and selected primers (200 nM; Table I). Each transcript was normalized to the amplification levels of GAPDH, which served as control. $\mathrm{C} / \mathrm{EBP} \beta$ mRNA levels were quantified by qPCR amplification. The following conditions were used: Pre-denaturing at $95^{\circ} \mathrm{C}$ for $5 \mathrm{~min}$ followed by 40 cycles of $95^{\circ} \mathrm{C}$ for $10 \mathrm{sec}, 60^{\circ} \mathrm{C}$ for $20 \mathrm{sec}$ and $72^{\circ} \mathrm{C}$ for $10 \mathrm{sec}$, and finally elongation at $72^{\circ} \mathrm{C}$ for $10 \mathrm{~min}$. Data analyses were conducted with the $2^{-\Delta \Delta \mathrm{Cq}}$ method (20). Each experiment was performed in triplicate.

MTT assay. $1 \times 10^{4}$ cells were seeded into each well of a 96-well plate. On the second day, the cells were infected with the lentiviruses $\mathrm{pCDH}, \mathrm{pCDH}-\mathrm{C} / \mathrm{EBP} \beta$, pLKO.1-shNC and $\mathrm{pLKO} .1-\mathrm{shC} / \mathrm{EBP} \beta$, respectively, to form the $\mathrm{pCDH}$, pCDH-C/EBP $\beta$, pLKO.1-shNC and pLKO.1-shC/EBP $\beta$ groups. Subsequently, the cells were incubated for 24,48 or $72 \mathrm{~h}$ at $37^{\circ} \mathrm{C}$ in a humidified atmosphere containing $5 \% \mathrm{CO}_{2}$. MTT (10 $\mu 1,5$ mg/ml; Shanghai Sangon Biotech Co., Ltd.) was added into each well at the same time of each day and the cells were then incubated for $4 \mathrm{~h}$. Dimethyl sulfoxide (DMSO; $100 \mu$; Shanghai Sangon Biotech Co., Ltd.) was added to each well to solubilize the formazan crystals. Zero (DMEM, MTT and DMSO) and blank wells were established. The absorbance 


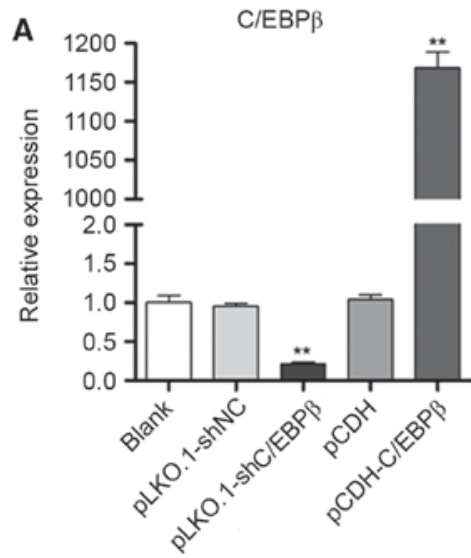

B

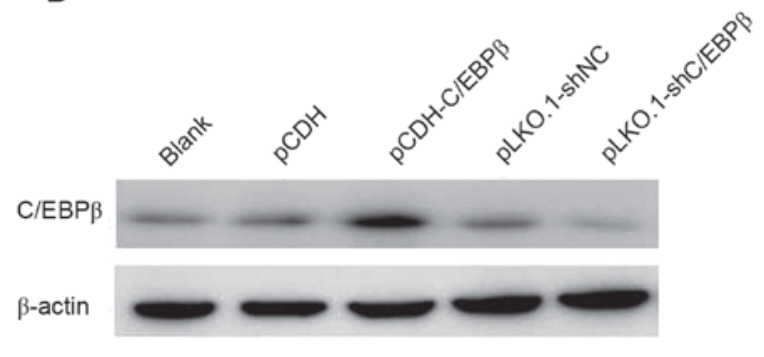

Figure 1. Lentiviral vectors pCDH-C/EBP $\beta$ and pLKO.1-shC/EBP $\beta$ were successfully constructed and had a high efficiency of infection. (A) Quantitative polymerase chain reaction analysis suggested that the mRNA expression levels of C/EBP $\beta$ were significantly increased in the $\mathrm{pCDH}-\mathrm{C} / \mathrm{EBP} \beta$ group and significantly decreased in the pLKO.1-shC/EBP $\beta$ group compared with pCDH and pLKO.1-shNC, respectively. (B) Western blotting indicated that the expression of $\mathrm{C} / \mathrm{EBP} \beta$ was increased in the $\mathrm{pCDH}-\mathrm{C} / \mathrm{EBP} \beta$ group and decreased in the pLKO.1-shC/EBP $\beta$ group compared with pCDH and pLKO.1-shNC, respectively. ${ }^{* *} \mathrm{P}<0.01$ vs. blank, $\mathrm{pCDH}$ and $\mathrm{pLKO}$.1-shNC groups. C/EBP $\beta$, CCAAT enhancer binding protein $\beta$; NC, negative control.

of each well was read at $570 \mathrm{~nm}$ using a microplate reader (Molecular Devices, LLC, Sunnyvale, CA, USA).

Flow cytometry. For cell cycle detection, infected cells cultured in DMEM from all groups were digested with $0.25 \%$ trypsin (Invitrogen; Thermo Fisher Scientific, Inc.), collected by centrifuging at $377 \mathrm{x}$ g for $6 \mathrm{~min}$ at $4^{\circ} \mathrm{C}$ and washed once with phosphate-buffered saline (PBS; Shanghai Sangon Biotech Co.). Cells were fixed with ice-cold $75 \%$ ethanol at $4^{\circ} \mathrm{C}$ overnight. Subsequently, cells were centrifuged $(377 \mathrm{x} \mathrm{g}$ for $6 \mathrm{~min}$ at $4^{\circ} \mathrm{C}$ ) and ethanol was removed by washing with PBS three times. Cells were slightly resuspended with $300 \mu \mathrm{l}$ PBS and treated with $50 \mu \mathrm{g} / \mathrm{ml}$ RNase A (Shanghai Sangon Biotech Co., Ltd.) for $30 \mathrm{~min}$ at $37^{\circ} \mathrm{C}$. Cells were stained with propidium iodide (PI; BioLegend, Inc., San Diego, CA, USA) in the dark for $15 \mathrm{~min}$ at $4^{\circ} \mathrm{C}$ and detected using a flow cytometer (BD Biosciences, San Jose, CA, USA). Data were analyzed by FCS Express 4 (De Novo Software, Los Angeles, CA, USA).

Annexin V-APC Apoptosis Detection kit (BD Biosciences) was used to detect cell apoptosis. Infected cells were digested with 0.25\% trypsin-EDTA (Invitrogen; Thermo Fisher Scientific, Inc.) and collected by centrifuging at $377 \mathrm{x}$ g for 6 min at $4^{\circ} \mathrm{C}$, then washed once with PBS. Cells were added to APC-Annexin V and $\mathrm{PI}$ in the dark for $15 \mathrm{~min}$ at $25^{\circ} \mathrm{C}$ after being slightly resuspended with $1 \mathrm{X}$ Binding Buffer. A total of $400 \mu \mathrm{l} 1 \mathrm{X}$ Binding Buffer was added and the cells were detected using a flow cytometer.

Cell migration and wound healing assay. Cell motility was measured using a wound healing assay. Cells from all groups were seeded onto $60-\mathrm{mm}$ plates and incubated in serum-free DMEM overnight at $37^{\circ} \mathrm{C}$. A P200 pipette tip was used to create an artificial wound by scratching the confluent cell monolayer. Immediately, a photomicrograph was taken (time $0 \mathrm{~h}$ ). Subsequently, at 24, 48 and $72 \mathrm{~h}$ post wounding, images were captured to observe the migrating cells and closure of the scratch wound. The wound areas were quantified using Muscale analysis software (Muscale LLC, Scottsdale, AZ, USA).

Western blotting. Cells from all groups were collected into $1.5-\mathrm{ml}$ tubes, washed twice with PBS, and then placed on ice for $30 \mathrm{~min}$ in radioimmunoprecipitation assay lysis buffer (Beyotime Institute of Biotechnology, Haimen, China) containing $1 \mathrm{mM}$ phenylmethylsulfonyl fluoride (Shanghai Sangon Biotech Co., Ltd.). Supernatant were acquired by centrifuging at $18894 \mathrm{x}$ g for $15 \mathrm{~min}$ at $4^{\circ} \mathrm{C}$. Subsequently, BCA protein quantitative assay was used to determine the protein concentration (Shanghai Sangon Biotech Co., Ltd.). A sample containing $40 \mu \mathrm{g}$ total protein was separated using $12 \%$ SDS-PAGE and transferred onto polyvinylidene difluoride membranes, which were blocked in $5 \%$ non-fat milk for $1 \mathrm{~h}$. The membranes were incubated overnight at $4^{\circ} \mathrm{C}$ with mouse anti-human $\beta$-actin monoclonal antibody $(1: 1,000$; sc-58673), rabbit anti-human C/EBP $\beta$ polyclonal antibody (1:500; sc-56637), mouse anti-human TGF $\beta 1$ monoclonal antibody (1:500; sc-146), rabbit anti-human Smad3 polyclonal antibody (1:800; sc-8332; all Santa Cruz Biotechnology, Inc., Dallas, TX, USA) and rabbit anti-human P-Smad3 polyclonal antibody (1:1,000; ab52903; Abcam, Cambridge, MA, USA). Membranes were washed three times with PBS and then incubated with secondary antibodies goat anti-mouse $\operatorname{IgG}(\mathrm{H}+\mathrm{L})-\mathrm{HRP}(1: 5,000)$ or goat anti-rabbit IgG (H+L)-HRP (1:5,000; both Jackson ImmunoResearch Laboratories, Inc., West Grove, PA, USA) for $2 \mathrm{~h}$ at room temperature, respectively. Proteins were detected using enhanced chemiluminescence (ECL; EMD Millipore, Billerica, MA, USA).

Statistical analysis. Statistical analysis in the present study was performed using SPSS 12.0 statistical analysis software (SPSS Inc., Chicago, IL, USA). All determinations were performed in triplicate. Data are expressed as the mean \pm standard deviation and analyzed by one-way analysis of variance and multiple comparisons between groups were performed using Student-Newman-Keuls method. $\mathrm{P}<0.05$ was considered to indicated a statistically significant difference.

\section{Results}

Identification oflentiviralvector $p C D H-C / E B P \beta$. Recombinant lentiviruses $\mathrm{pCDH}-\mathrm{C} / \mathrm{EBP} \beta$ and $\mathrm{pLKO} .1$-shC/EBP $\beta$ were efficiently infected into MDA-MB-468 cells (Fig. 1A), respectively. Western blotting indicated that the protein expression level of 

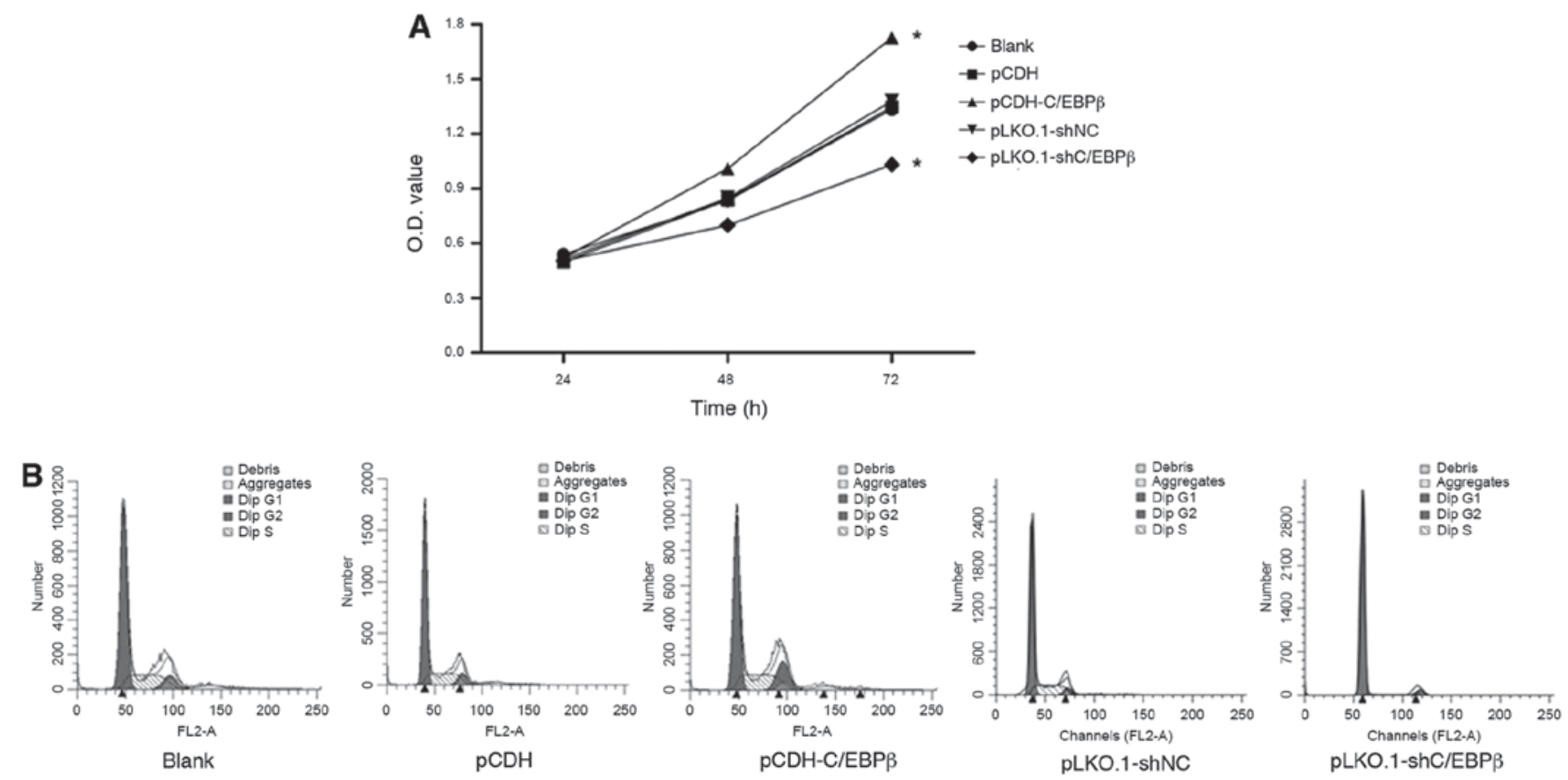

Figure 2. C/EBP $\beta$ regulated MDA-MB-468 cell viability and the cell cycle. (A) MTT analysis showed that the absorbance of MDA-MB-468 cells was significantly increased in the $\mathrm{pCDH}-\mathrm{C} / \mathrm{EBP} \beta$ group compared with the blank and $\mathrm{pCDH}$ groups after 48 and $72 \mathrm{~h}$. Absorbance in the $\mathrm{pLKO}$.1-shC/EBP $\beta$ group was significantly decreased compared with that in the blank and pLKO.1-shNC groups after 48 and $72 \mathrm{~h}$. (B) Flow cytometric analysis indicated that, compared with the $\mathrm{pCDH}$ and blank groups, the proportion of cells of the $\mathrm{pCDH}-\mathrm{C} / \mathrm{EBP} \beta$ group in the G1 phase decreased and that in the $\mathrm{G} 2 \mathrm{phase}$ increased. The proportion of cells in the G1 phase was increased and in the G2 phase was decreased in the pLKO.1-shC/EBP $\beta$ cells. "P<0.05 vs. the blank, pCDH and pLKO.1-shNC groups. C/EBP $\beta$, CCAAT enhancer binding protein $\beta$; NC, negative control; O.D., optical density.
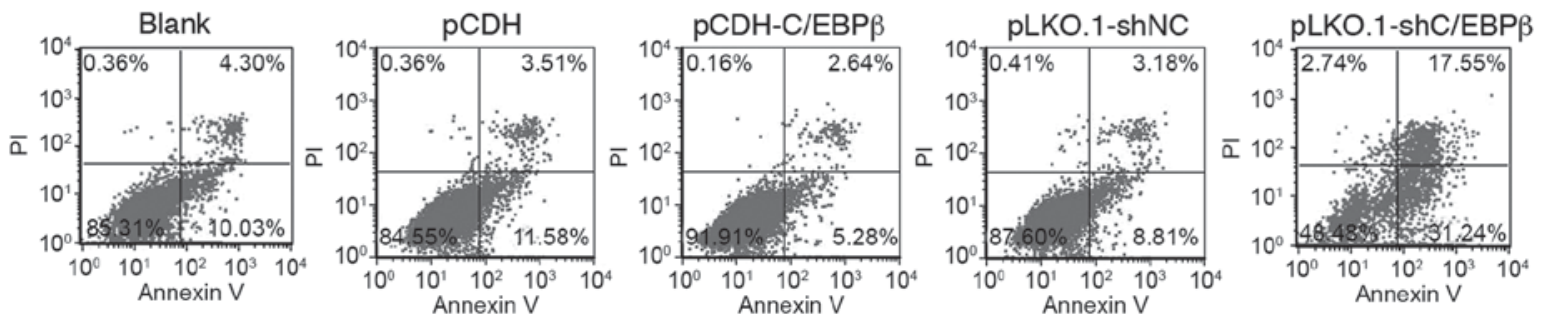

Figure 3. C/EBP $\beta$ affected the apoptosis of MDA-MB-468 cells. Flow cytometric analysis revealed that the apoptotic cell ratio was decreased in the $\mathrm{pCDH}-\mathrm{C} / \mathrm{EBP} \beta$ group compared with the $\mathrm{pCDH}$ and blank groups; however, the apoptotic cell ratio was increased in the $\mathrm{pLKO}$.1-shC/EBP $\beta$ group. C/EBP $\beta$, CCAAT enhancer binding protein $\beta$; NC, negative control; PI, propidium iodide.

$\mathrm{C} / \mathrm{EBP} \beta$ was markedly increased in the $\mathrm{pCDH}-\mathrm{C} / \mathrm{EBP} \beta$ group, whereas the protein expression level of $\mathrm{C} / \mathrm{EBP} \beta$ was markedly decreased in the $\mathrm{pLKO} .1$-shC/EBP $\beta$ group when compared with the blank control (Fig. 1B). These results demonstrated that lentiviral vector $\mathrm{pCDH}-\mathrm{C} / \mathrm{EBP} \beta$ and $\mathrm{pLKO}$.1-shC/EBP $\beta$ were successfully constructed and that the lentiviruses (including $\mathrm{pCDH}-\mathrm{C} / \mathrm{EBP} \beta, \mathrm{pCDH}, \mathrm{pLKO} .1-\mathrm{shC} / \mathrm{EBP} \beta$ and pLKO.1-shNC) had a high efficiency of infection.

Effect of $C / E B P \beta$ on cell viability and cell cycle in MDA-MB-468 cells. MTT analysis was performed to observe the cell viability after infection. As Fig. 2A indicates, the absorbance of the MDA-MB-468 cells was significantly increased in the $\mathrm{pCDH}-\mathrm{C} / \mathrm{EBP} \beta$ group at 48 and $72 \mathrm{~h}$ compared with that of the $\mathrm{pCDH}$ and blank groups $(\mathrm{P}<0.05)$. Conversely, cell viability was significantly diminished in the $\mathrm{pLKO}$.1-shC/EBP $\beta$ group compared with that in the pLKO.1-shNC and blank groups $(\mathrm{P}<0.05)$. These data suggest that $\mathrm{C} / \mathrm{EBP} \beta$ has an important role in cell viability.
Cell cycle analysis was performed using flow cytometry, and the results demonstrated that the percentage of MDA-MB-468 cells in the G1 phase was significantly decreased and that in the $\mathrm{G} 2$ phase was significantly increased in the $\mathrm{pCDH}-\mathrm{C} / \mathrm{EBP} \beta$ group compared with the blank and $\mathrm{pCDH}$ groups $(\mathrm{P}<0.05$; Fig. 2B and Table II). Furthermore, the percentage of cells in the $\mathrm{Gl}$ phase in the $\mathrm{pLKO}$.1-shC/EBP $\beta$ group was significantly increased compared with that in the blank and pLKO.1-shNC groups $(\mathrm{P}<0.05$; Fig. 2B and Table II). These results suggest that cells in the pLKO.1-shC/EBP $\beta$ group were blocked at the G1 boundary, which concomitantly reduced the proportion of cells in the S phase (Fig. 2B and Table II).

Effect of C/EBP $\beta$ on cell apoptosis in MDA-MB-468 cells. The apoptotic ratio of the cells was quantitatively analyzed using flow cytometry. As shown in Fig. 3 and Table III, the apoptotic cell ratio was significantly decreased in the $\mathrm{pCDH}-\mathrm{C} / \mathrm{EBP} \beta$ group compared with the blank and $\mathrm{pCDH}$ groups $(\mathrm{P}<0.05)$; however, the apoptotic cell level was significantly increased 
Table II.Cell cycle analysis in the blank, pCDH,pCDH-C/EBP $\beta$, pLKO.1-shNC and pLKO.1-shC/EBP $\beta$ groups.

\begin{tabular}{lccc}
\hline Group & $\begin{array}{c}\text { G1 phase } \\
(\%)\end{array}$ & $\begin{array}{c}\text { S phase } \\
(\%)\end{array}$ & $\begin{array}{c}\text { G2 phase } \\
(\%)\end{array}$ \\
\hline Blank & $62.79 \pm 1.06$ & $27.87 \pm 1.36$ & $9.31 \pm 1.09$ \\
pCDH & $64.83 \pm 1.69$ & $28.18 \pm 1.35$ & $8.42 \pm 0.75$ \\
pCDH-C/EBP $\beta$ & $55.13 \pm 1.13^{\mathrm{a}, \mathrm{b}}$ & $26.21 \pm 1.95$ & $18.67 \pm 0.73^{\mathrm{a}, \mathrm{b}}$ \\
pLKO.1-shNC & $66.08 \pm 3.50$ & $27.91 \pm 1.02$ & $5.75 \pm 0.62$ \\
pLKO.1-shC/ & $91.62 \pm 2.83^{\mathrm{a}, \mathrm{c}}$ & $4.21 \pm 0.23^{\mathrm{a}, \mathrm{c}}$ & $4.13 \pm 0.29$ \\
EBP $\beta$ & & & \\
\hline
\end{tabular}

${ }^{\mathrm{a}} \mathrm{P}<0.05$ vs. the blank group; ${ }^{\mathrm{b}} \mathrm{P}<0.05$ vs. the $\mathrm{pCDH}$ group; ${ }^{\mathrm{c}} \mathrm{P}<0.05$ vs. the pLKO.1-shNC group. C/EBP $\beta$, CCAAT enhancer binding protein $\beta ; \mathrm{NC}$, negative control.

A

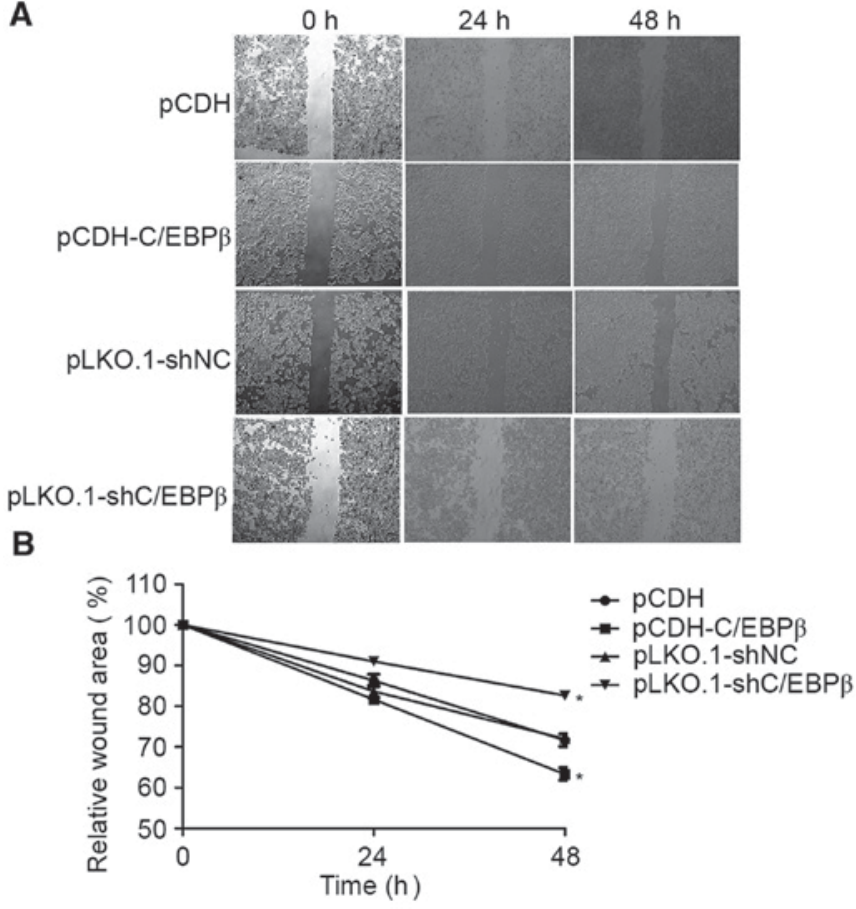

Figure 4. C/EBP $\beta$ depletion inhibits MDA-MB-468 cell motility. (A) Scratch-wound assays showed that MDA-MB-468 cells depleted of $\mathrm{C} / \mathrm{EBP} \beta$ filled in less of the scratch area compared with the cells in the pLKO.1-shNC group, while increased C/EBP $\beta$ expression increased the motility of MDA-MB-468 cells. (B) Relative wound area in each group. C/EBP $\beta$, CCAAT enhancer binding protein $\beta$; NC, negative control. ${ }^{*} \mathrm{P}<0.05$ vs. the $\mathrm{pLKO}$.1-shNC and $\mathrm{pCDH}$ groups.

in the pKLO.1-shC/EBP $\beta$ group compared with the blank and pLKO.1-shNC groups ( $\mathrm{P}<0.05$; Fig. 3 and Table III). These results suggest that the expression of $\mathrm{C} / \mathrm{EBP} \beta$ decreases cell apoptosis.

$C / E B P \beta$ depletion inhibits MDA-MB-468 cell motility. Scratch-wound assays were performed to assess the role of $\mathrm{C} / \mathrm{EBP} \beta$ in MDA-MB-468 cell motility. These assays showed that MDA-MB-468 cells with overexpressed C/EBP $\beta$ exhibited significantly increased motility, whereas the cells depleted of $C / E B P \beta$ exhibited significantly decreased motility as they did not fill in the scratch as extensively as did cells from the control groups $(\mathrm{P}<0.05$; Fig. 4).
Table III. Cell apoptosis in the blank, $\mathrm{pCDH}, \mathrm{pCDH}-\mathrm{C} / \mathrm{EBP} \beta$, pLKO.1-shNC and pLKO.1-shC/EBP $\beta$ groups.

\begin{tabular}{lc}
\hline Group & Apoptotic cell ratio (\%) \\
\hline Blank & $14.46 \pm 0.89$ \\
pCDH & $15.32 \pm 1.86$ \\
pCDH-C/EBP $\beta$ & $7.49 \pm 0.51^{\mathrm{a}, \mathrm{b}}$ \\
pLKO.1-shNC & $12.14 \pm 0.94$ \\
pLKO.1-shC/EBP $\beta$ & $48.21 \pm 1.97^{\mathrm{a}, \mathrm{c}}$
\end{tabular}

${ }^{\mathrm{a}} \mathrm{P}<0.05$ vs. the blank group; ${ }^{\mathrm{b}} \mathrm{P}<0.05$ vs. the $\mathrm{pCDH}$ group; ${ }^{\mathrm{C}} \mathrm{P}<0.05$ vs. the pLKO.1-shNC group. C/EBP $\beta$, CCAAT enhancer binding protein $\beta ; \mathrm{NC}$, negative control.

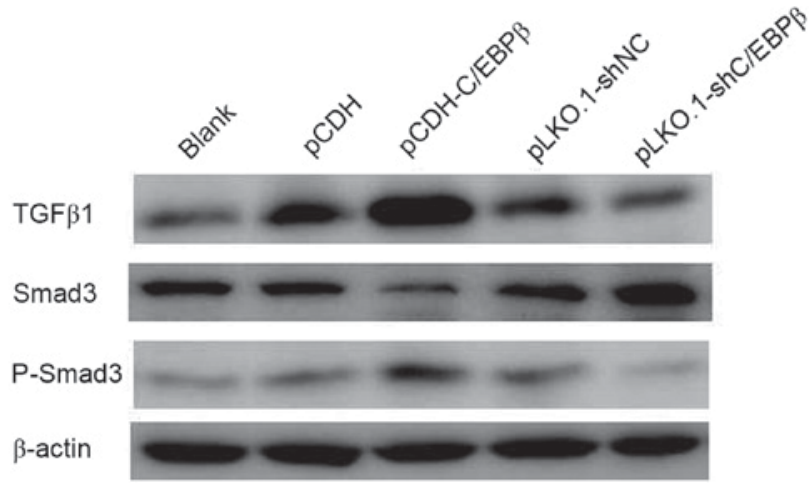

Figure 5. C/EBP $\beta$ affected the expression of TGF- $\beta 1$ by Smad3 expression. Western blotting indicated that the expression levels of TGF $\beta 1$ and $\mathrm{P}-\mathrm{Smad} 3$ were increased and the expression level of Smad3 was decreased in the $\mathrm{pCDH}-\mathrm{C} / \mathrm{EBP} \beta$ group compared with the $\mathrm{pCDH}$ and blank groups. By contrast, the TGF 31 and P-Smad3 expression levels were decreased and the expression level of Smad3 was increased in the $\mathrm{pLKO}$.1-shC/EBP $\beta$ group $\mathrm{C} / \mathrm{EBP} \beta, \mathrm{CCAAT}$ enhancer binding protein $\beta$; TGF $\beta 1$, transforming growth factor $\beta 1$; NC, negative control.

Effect of overexpression of C/EBP $\beta$ onTGF $\beta 1$-Smad3 signaling in MDA-MB-468 cells. To investigate the mechanism by which C/EBP $\beta$ affects MDA-MB-468 cells, the protein expression levels of TGF $\beta 1$, P-Smad3 and Smad3 were detected. Western blotting indicated that TGF $\beta 1$ and P-Smad3 protein expression levels were increased in the $\mathrm{pCDH}-\mathrm{C} / \mathrm{EBP} \beta$ group and decreased in $\mathrm{pLKO} .1$-shC/EBP $\beta$ group when compared with those in the respective control groups (Fig. 5). Conversely, a marked reduction in the protein expression level of Smad3 was observed in the $\mathrm{pCDH}-\mathrm{C} / \mathrm{EBP} \beta$ group, whereas Smad3 expression was notably increased in the $\mathrm{pLKO} .1$-shC/EBP $\beta$ group compared with the respective control groups (Fig. 5).

\section{Discussion}

In recent years, the morbidity of breast cancer has increased, despite considerable achievements being made in tumor therapy (21). It has been reported that $\mathrm{C} / \mathrm{EBP} \beta$ expression may be used to predict the overall survival in breast cancer patients, since it affects tumor growth and metastasis formation in mice (22). In the present study, the effect of $C / E B P \beta$ 
on a breast cancer cell line and the molecular mechanism of its effect were investigated. The present results showed that overexpression of $\mathrm{C} / \mathrm{EBP} \beta$ significantly increased breast cancer cell viability and concomitantly decreased the cell apoptosis rate. Western blotting results suggested that overexpression of $\mathrm{C} / \mathrm{EBP} \beta$ increased the protein expression levels of TGF $\beta 1$ and P-Smad3 and repressed the expression of Smad3.

The present study demonstrated that the overexpression of $\mathrm{C} / \mathrm{EBP} \beta$ promoted viability and inhibited apoptosis, and knockdown of $\mathrm{C} / \mathrm{EBP} \beta$ inhibited cell viability and promoted apoptosis in MDA-MB-468 cells. The role of C/EBP $\beta$ in the regulation of cell viability and apoptosis in the present study is partly consistent with previous studies in other cancer cell lines. For example, Buck et al (23) observed that the expression of $\mathrm{C} / \mathrm{EBP} \beta$ had an important role in the survival of hepatic stellate cells with DNA damage caused by $\mathrm{CCl}_{4}$-induced free radicals. The ability of cancer cells to invade into surrounding tissue is affected by their motility as well as their ability to penetrate through tissue barriers, such as the extracellular matrix. Wound assay results in the present study suggested that the overexpression of $\mathrm{C} / \mathrm{EBP} \beta$ increased cell motility, suggesting the potential role of $\mathrm{C} / \mathrm{EBP} \beta$ in cancer metastasis.

Previous studies have suggested that $\mathrm{C} / \mathrm{EBP} \beta$ has antiproliferative effects in various normal cells. For example, $\mathrm{C} / \mathrm{EBP} \beta$ was demonstrated to inhibit cell proliferation through interacting with the retinoblastoma protein family to suppress the expression of E2F target genes ( $\mathrm{S}$-phase genes) in primary fibroblasts (24). Furthermore, decreased expression of $\mathrm{C} / \mathrm{EBP} \beta$ enabled primary keratinocytes to resist calcium-induced growth arrest (25). The results of the present study are consistent with other data. In a previous study, knockdown of C/EBP $\beta$ significantly inhibited glioblastoma cell proliferation and invasion, and also prolonged survival in a murine brain tumor model (26). Additionally, another study demonstrated that $\mathrm{C} / \mathrm{EBP} \beta^{-/-}$mice were completely resistant to tumorigenic agents applied to the skin due to the Ras-dependent promotion of apoptosis (8). Also, growth-promoting activity of $\mathrm{C} / \mathrm{EBP} \beta$ has been observed in mammary epithelial cells (27) and hepatic cells (28). By consideration of the previous and present study results, it may be proposed that $\mathrm{C} / \mathrm{EBP} \beta$ has an accelerative role in breast cancer development by controlling cell proliferation and apoptosis.

The present study investigated the molecular mechanism of $\mathrm{C} / \mathrm{EBP} \beta$ and indicated that $\mathrm{C} / \mathrm{EBP} \beta$ promoted cell viability in MDA-MB-468 cells. Furthermore, the results indicated that it affected the expression levels of proteins associated with the TGF- $\beta 1$-Smad3 signaling pathway. A previous study showed that increased $\mathrm{C} / \mathrm{EBP} \beta$ expression elevated transcription activity of the TGF- $\beta 1$ promoter in human primary astrocytes and microglial cells (29). The present results demonstrated that overexpression of $\mathrm{C} / \mathrm{EBP} \beta$ increased the expression of TGF- $\beta 1$ and $\mathrm{P}-\mathrm{Smad} 3$, suggesting that $\mathrm{C} / \mathrm{EBP} \beta$ promoted TGF- $\beta$-Smad 3 signaling by activating the TGF $\beta 1$ promoter in breast cancer. Notably, the present study also revealed that the protein expression levels of Smad3 were strongly inhibited in the pCDH-C/EBP $\beta$ group. Smad3 has previously been demonstrated to inhibit the activity of $\mathrm{C} / \mathrm{EBP} \beta$ on transcribing monocyte chemoattractant protein-1, inducible nitric oxide synthase and haptoglobin promoter by interacting with $\mathrm{C} / \mathrm{EBP} \beta$ (30-32). Additionally, the MH2 domain of Smad3 has been shown to combine with $\mathrm{C} / \mathrm{EBP} \beta$, and subsequently decrease the association between $\mathrm{C} / \mathrm{EBP} \beta$ and TGF- $\beta 1$ promoter, suggesting that the increased expression of Smad3 inhibited the activity of C/EBP $\beta$ on the TGF- $\beta 1$ promoter $(29,33)$. Thus, it may be speculated that inhibited Smad3 expression further promoted the activity of $\mathrm{C} / \mathrm{EBP} \beta$ on the TGF- $\beta 1$ promoter via a positive feedback mechanism. A previous study indicated that TGF $\beta$ had an antiproliferative effect on epithelial cells, astrocytes and immune cells; however, in certain malignant tumors the capacity of TGF $\beta$ to inhibit proliferation is selectively lost (34) and TGF- $\beta 1$ is considered as an oncogenic factor (16). The present results indicated that $\mathrm{C} / \mathrm{EBP} \beta$ may promote MDA-MB-468 cell growth through activating TGF- $\beta$ signaling.

In conclusion, the present study demonstrated that $\mathrm{C} / \mathrm{EBP} \beta$ has a crucial role in regulating breast cancer cell growth through the activation of TGF- $\beta$-Smad 3 signaling. These findings suggest that $\mathrm{C} / \mathrm{EBP} \beta$ may be a potential therapeutic target for breast cancer, although in vivo studies in animal models are required to confirm this.

\section{References}

1. Siegel R, Naishadham D and Jemal A: Cancer statistics, 2013. CA Cancer J Clin 63: 11-30, 2013.

2. Nguyen DX, Bos PD and Massagué J: Metastasis: From dissemination to organ-specific colonization. Nat Rev Cancer 9: 274-284, 2009.

3. Osada S, Yamamoto H, Nishihara T and Imagawa M: DNA binding specificity of the CCAAT/enhancer-binding protein transcription factor family. J Biol Chem 271: 3891-3896, 1996.

4. Poli V: The role of $\mathrm{C} / \mathrm{EBP}$ isoforms in the control of inflammatory and native immunity functions. J Biol Chem 273: 29279-29282, 1998.

5. Ramji DP and Foka P: CCAAT/enhancer-binding proteins: Structure, function and regulation. Biochem J 365: 561-575, 2002.

6. Cortés-Canteli M, Pignatelli M, Santos A and Perez-Castillo A: CCAAT/enhancer-binding protein beta plays a regulatory role in differentiation and apoptosis of neuroblastoma cells. J Biol Chem 277: 5460-5467, 2002.

7. Cortes-Canteli M, Wagner M, Ansorge W and Pérez-Castillo A: Microarray analysis supports a role for ccaat/enhancer-binding protein-beta in brain injury. J Biol Chem 279: 14409-14417, 2004.

8. Zhu S, Yoon K, Sterneck E, Johnson PF and Smart RC: CCAAT/enhancer binding protein-beta is a mediator of keratinocyte survival and skin tumorigenesis involving oncogenic Ras signaling. Proc Natl Acad Sci USA 99: 207-212, 2002.

9. Ewing SJ, Zhu S, Zhu F, House JS and Smart RC: C/EBPbeta represses p53 to promote cell survival downstream of DNA damage independent of oncogenic Ras and p19 (Arf). Cell Death Differ 15: 1734-1744, 2008.

10. Zahnow CA: CCAAT/enhancer binding proteins in normal mammary development and breast cancer. Breast Cancer Res 4: 113-121, 2002.

11. Gomis RR, Alarcón C, Nadal C, Van Poznak C and Massagué J: $\mathrm{C} / \mathrm{EBPbeta}$ at the core of the TGFbeta cytostatic response and its evasion in metastatic breast cancer cells. Cancer Cell 10: 203-214, 2006.

12. Johansson J, Berg T, Kurzejamska E, Pang MF, Tabor V, Jansson M, Roswall P, Pietras K, Sund M, Religa P and Fuxe J: MiR-155-mediated loss of C/EBP $\beta$ shifts the TGF- $\beta$ response from growth inhibition to epithelial-mesenchymal transition, invasion and metastasis in breast cancer. Oncogene 32: 5614-5624, 2013.

13. Coyle-Rink J, Sweet T, Abraham S, Sawaya B, Batuman O, Khalili K and Amini S: Interaction between TGFbeta signaling proteins and C/EBP controls basal and Tat-mediated transcription of HIV-1 LTR in astrocytes. Virology 299: 240-247, 2002. 
14. Kaminska B, Wesolowska A and Danilkiewicz M: TGF beta signalling and its role in tumour pathogenesis. Acta Biochim Pol 52: 329-337, 2005.

15. Seoane J: The TGFBeta pathway as a therapeutic target in cancer. Clin Transl Oncol 10: 14-19, 2008

16. Wrana JL, Attisano L, Cárcamo J, Zentella A, Doody J, Laiho M, Wang XF and Massagué J: TGF beta signals through a heteromeric protein kinase receptor complex. Cell 71: 1003-1014, 1992.

17. Wang P, Yu J, Yin Q, Li W, Ren X and Hao X: Rosiglitazone suppresses glioma cell growth and cell cycle by blocking the transforming growth factor-beta mediated pathway. Neurochem Res 37: 2076-2084, 2012.

18. Eichhorn PJ, Rodón L, Gonzàlez-Juncà A, Dirac A, Gili M, Martínez-Sáez E, Aura C, Barba I, Peg V, Prat A, et al: USP15 stabilizes TGF- $\beta$ receptor I and promotes oncogenesis through the activation of TGF- $\beta$ signaling in glioblastoma. Nat Med 18: 429-435, 2012.

19. Kaminska B, Kocyk M and Kijewska M: TGF beta signaling and its role in glioma pathogenesis. Adv Exp Med Biol 986: 171-187, 2013.

20. Livak KJ and Schmittgen TD: Analysis of relative gene expression data using real-time quantitative PCR and the 2(-Delta Delta C(T)) Method. Methods 25: 402-408, 2001.

21. Parks RM and Cheung KL: Patient pathway for breast cancer: Turning points and future aspirations. Future Oncol 11 $1059-1070,2015$

22. Kurzejamska E, Johansson J, Jirström K, Prakash V, Ananthaseshan S, Boon L, Fuxe J and Religa P: C/EBP $\beta$ expression is an independent predictor of overall survival in breast cancer patients by MHCII/CD4-dependent mechanism of metastasis formation. Oncogenesis 3: e125, 2014.

23. Buck M, Poli V, Hunter T and Chojkier M: C/EBPbeta phosphorylation by RSK creates a functional XEXD caspase inhibitory box critical for cell survival. Mol Cell 8: 807-816, 2001.

24. Sebastian T, Malik R, Thomas S, Sage J and Johnson PF: C/EBPbeta cooperates with RB:E2F to implement Ras(V12)-induced cellular senescence. EMBO J 24: 3301-3312, 2005 .
25. Zhu S, Oh HS, Shim M, Sterneck E, Johnson PF and Smart RC: C/EBPbeta modulates the early events of keratinocyte differentiation involving growth arrest and keratin 1 and keratin 10 expression. Mol Cell Biol 19: 7181-7190, 1999.

26. Aguilar-Morante D, Cortes-Canteli M, Sanz-Sancristobal M, Santos A and Perez-Castillo A: Decreased CCAAT/enhancer binding protein $\beta$ expression inhibits the growth of glioblastoma cells. Neuroscience 176: 110-119, 2011

27. Bundy LM and Sealy L: CCAAT/enhancer binding protein beta (C/EBPbeta)-2 transforms normal mammary epithelial cells and induces epithelial to mesenchymal transition in culture. Oncogene 22: 869-883, 2003.

28. Buck M, Poli V, van der Geer P, Chojkier M and Hunter T: Phosphorylation of rat serine 105 or mouse threonine 217 in $\mathrm{C} / \mathrm{EBP}$ beta is required for hepatocyte proliferation induced by TGF alpha. Mol Cell 4: 1087-1092, 1999.

29. Abraham S, Sweet T, Khalili K, Sawaya BE and Amini S: Evidence for activation of the TGF-betal promoter by C/EBPbeta and its modulation by Smads. J Interferon Cytokine Res 29: 1-7, 2009.

30. Abraham S, Sweet T, Sawaya BE, Rappaport J, Khalili K and Amini S: Cooperative interaction of C/EBP beta and Tat modulates MCP-1 gene transcription in astrocytes. J Neuroimmunol 160: 219-227, 2005.

31. Feinberg MW, Watanabe M, Lebedeva MA, Depina AS, Hanai J, Mammoto T, Frederick JP, Wang XF, Sukhatme VP and Jain MK: Transforming growth factor-betal inhibition of vascular smooth muscle cell activation is mediated via Smad3. J Biol Chem 279: 16388-16393, 2004.

32. Zauberman A, Lapter S and Zipori D: Smad proteins suppress CCAAT/enhancer-binding protein (C/EBP) beta- and STAT3-mediated transcriptional activation of the haptoglobin promoter. J Biol Chem 276: 24719-24725, 2001.

33. Wotton D and Massagué J: Smad transcriptional corepressors in TGF beta family signaling. Curr Top Microbiol Immunol 254: 145-164, 2001

34. Seoane J: Escaping from the TGFbeta anti-proliferative control. Carcinogenesis 27: 2148-2156, 2006. 